\title{
Paradigma al-Qur'an: Model Analisis Tafsir Maqasidi dalam Pemikiran Kuntowijoyo
}

\section{KUSMANA}

UIN Syarif Hidayatullah Jakarta

Email: kusmana@uinjkt.ac.id

\section{ABSTRACT}

This article assumes that Kuntowijoyo's thought can be grouped into the maqasidi thought movement, because of his treatment of the objectivication of the verses of the Qur'an in search for God's intention based on the scientific measurement. His difference from the thinkers of maqasidi in general lies on the use of epistemology. Maqasidi thinkers uses in general usul al-fiqh as their epistemological tool of analysis, whereas Kuntowijoyo deploys social sciences' epistemology. This library research finds that the characteristics of Kuntowijoyo's interpretation of the Qur'an can be included into the spirit of maqasidi scientific interpretation with a tendency of constructing scientific knowledge based on the Qur'an. His characteristics of tafsir maqasidi can be grouped as manhaj din (religious methodology) atau in his word, (Quranic paradigm.)

Keywords: Kata Kunci: Tafsir Maqasidi, Maqasid Syari 'ah, Epistemologi.

\section{ABSTRAK}

Tulisan ini mengasumsikan bahwa gagasan yang dikembangkan Kuntowijoya dapat dikelompokkan ke dalam gerakan pemikiran maqasidi. Dasar obyektifikasi ayat-ayat al-Qur'an yang dilakukannya mencoba mengidentifikasi tujuan Tuhan dalam firman-Nya dengan implementasi prinsip ilmiah. Bedanya dari para pemikir maqasidi terletak pada epistemologi yang digunakan. Pada umumnya pemikir Muslim Muslim menggunakan usul al-figh, sementara Kuntowijoyo menggunakan epistemologi ilmu sosial. Tulisan yang didasarkan studi kepustakaan ini menemukan bahwa corak tafsirnya dapat dikelompokkan ke dalam semangat tafsir maqasidi ilmi dengan kecenderungan untuk mengkonstruksi ilmu pengetahuan dengan inspirasi input Qur'ani. Pengertian maqasidi dari tulisannya dapat dikategorikan mengambil makna sebagai manhaj din (metodologi keagamaan) atau dalam bahasa Kuntowijoyo paradigma al-Qur'an.

Kata Kunci: Tafsir Maqasidi, Maqasid Syari 'ah, Epistemologi. 


\section{PENDAHULUAN}

Manhaj maqasidi, pada awalnya dikembangkan dalam tradisi hukum Islam. Dalam perkembangannya, banyak sarjana telah menggunakan pendekatan ini untuk memahami dan menafsirkan sumber ajaran Islam, khususnya alQur'an, seperti Rashid Rida (w. 1354 H/1935 M), Al-Tahir ibn Ashur (w. 1325 H/ 1907 M), Mohammad al-Ghazaly (w. 1416 H/ 1996 M), Yusuf al-Qaradawi (1345/1926 -), Taha al-Alwani (1354/ 1935 -), dll. Penggunaan pendekatan tersebut dimungkinkan karena konsep al-maqasid yang memungkinkan untuk memelihara signifikansi Islam bagi manusia. Konsep ini meliputi wilayah hermeneutika fikih yang pada dasarnya bermakna deciphering atau memahami, seperti memahami pesan Allah untuk digunakan bagi kebaikan manusia dan semesta alam. Prinsip dasar pendekatan maqasidi adalah memelihara pesan universal al-Qur'an untuk menjawab kekhususan dan perbedaan masalah yang dihadapi manusia.

Pada awalnya, konsepsi maqasid didasarkan pada tiga pertimbangan dasar, yaitu darurat (necessities/keniscayaan), hajiyyat (needs/kebutuhan), dan tahsiniyyat (/uxuries/kelengkapan hidup), dimana pertimbangan dasar pertama menjadi pokok ukuran yang secara tradisional didasarkan pada pemeliharaan lima hal: keimanan (faith), jiwa (soul), kekayaan (wealth), akal (mind), dan keturunan (offspring), dan sebagian menambahkan kehormatan (honor). ${ }^{1} \mathrm{Na}$ mun dalam perkembangannya, penggunaan konsep maqasidi tidak hanya didasarkan pada pertimbangan individual seperti tercermin dalam pengertiannya yang tradisional, tapi juga dimensi prisnsip dasarnya diperluas kepertimbangan nilai-nilai universal, yaitu maqasid universal, dimana proses tafsir atau ijtihad didasarkan pada dasar-dasar universal yang terdapat dalam Islam khususnya dalam al-Qur'an. Jasser Auda memformulasikan maqasid sebagai struktur multidimensi yang mempertimbangkan area makna dan target, tingkatan nilai yang dijadikan dasar, dan keumuman makna yang dikandung. ${ }^{2}$ Dengan pengertian tersebut, pengertian maqasid mengalami transformasi ke arah lebih luas, umum dan universal. Misalnya, Al-Tahir ibn Asyur mengusulkan perluasan dasar pertimbangan maqasid pada menjaga dan memelihara ketertiban (orderliness), kesejajaran (equality), kebebasan (freedom), facilitation (pendasaran untuk menciptakan keadaan yang membantu), dan pemeliharaan fitrah (kualitas alamiah akal dan sifat-sifat manusia). ${ }^{3}$

Dari sisi nilai universal yang diinterpolasikan ke dalam dimensi baru, maqasid adalah kebebasan, keadilan, kesetaraan, dan hak azasi manusia. Dengan pertimbangan tersebut, sarjana Muslim mendapat amunisi baru untuk 
merespon tantangan zaman. Yusuf al-Qaradhawi mengelompokkan respons tersebut ke dalam tiga pendekatan tafsir maqasidi: literalis atau zhahirriyyah yang menitikberatkan pada penafsiran berdasarkan redaksi al-Qur'an semata, liberalis yang menekankan pada penafsiran esensi walaupun mesti meninggalkan isyarat yang termuat secara tekstual, dan moderat yang mempertimbangkan kebaikan dari dua pendekatan sebelumnya dengan fokus menjaga pesan global al-Qur'an. ${ }^{4}$

Dalam konteks Indonesia, penggunaan metode tafsir seperti tematik, tahlili dan ijtima'i sudah mulai ramai digunakan, termasuk corak tafsir maqasidi. Walaupun belum secara tegas mengkhususkan penggunaan konsep maqasidi, banyak dari pemikir dan penafsir Muslim Indonesia yang menggunankan konsep maqasidi sebagai rujukan dalam merespon berbagai persoalan modern, termasuk persoalan agensi perempuan. Misalnya, Husein Muhammad dalam merumuskan pikirannya tentang keadilan gender mendasarkan rumusannya pada prinsip-prinsip maqasidi, yaitu tujuan kemanusian univerversal dengan empat dimensi makna: kemaslahatan, keadilan, kerahmatan, dan kebijaksanaan. ${ }^{5}$ Sejalan dengan Muhammad, M. Qurasih Shihab juga mendasarkan pembahasan tentang jender dan khususnya perempuan pada prinsip-prinsip dasar yang universal. Dalam satu tulisan, dia mendiskusikan perempuan dari sisi kejadian, hak, kedudukan dan peran perempuan. ${ }^{6}$ Penggunaan terma-terma tersebut mengindikasikan bahwa Quraish Shihab sedang melakukan upaya relevansi Islam dengan zaman modern dengan cara melihat dari perspektif sumber-sumber Islam dan mengaitkannya pada istilahistitilah yang biasa digunakan dalam kesarjanaan modern. Contoh lainnya misalnya tulisan Muhammad Yusuf yang mengidentifikan penggunaan pendekatan al-maslahah al-mursalah dalam proses perumusan fatwa MUI tentang nikah beda agama. Dalam tulisannya Yusuf menempatkan konsep almaslahah al-mursalah sebagai bagian dari cara kerja maqasid Syari'ah dalam pengertiannya yang klasik dimana tiga dasar - darurat, hajiyyat, dan tahsiniyyat, dijadikan ukuran aplikasi konsep. ${ }^{7}$ Contoh pertama merupakan aplikasi tafsir maqasid dengan semangat untuk mencari alternatif penafsiran yang berkeadilan gender, sementara ke dua dan ke tiga merupakan contoh aplikasi yang menjaga makna relasi gender yang mapan.

Dari penjelasan di atas setidaknya terdapat dua cara penggunaan maqasid syari'ah. Pertama, pendekatan maqasidi Syari'ah dibahas dalam perspektif hukum Islam. Hal ini dapat dimengerti karena Syari'ah itu sendiri lebih dimaknai sebagai tasyri', sehingga kalau disebut maqasidi Syari'ah maka yang dimaksud 
adalah deduksi hukum Islam dengan mempertimbangkan maksud-maksud umum Syari'ah. Kedua, maqasid syari'ah dalam pengertian sebagai manhaj agama.

Dalam hal ini dapat dilihat bahwa baik maqasid syari'ah dalam pengertian tasyri' atau dalam pengertian manhaj sama-sama berpotensi dapat dimanfaatkan sebagai pendekatan pengilmuan Islam. Pertama, menarik untuk melihat tawaran Jaser Audah tentang filsafat sistimatis hukum Islam yang dibangun berdasarkan maqasid syari'ah. Dalam bukunya, Maqasid al-Shari'ah: Dalil li al-Mubtadi (2011) diterjemahkan dalam bahasa Inggris Maqasid alShari'ah as Philosophy of Islamic Law: a System Approach dengan meminjam tradisi filsafat Barat merumuskan tawaran deduksi hukum yang menyeluruh didasarkan pada maksud-maksud syari'ah tapi dengan pendekatan sistematik untuk memelihara tujuan utama syari'ah yang dapat menjawab tantangan zaman. Pertimbangan utama dalam melakukan ijtihad penafsiran kembali khasanah Islam dengan cara menjadikan maqasid Syari'ah sebagai common ground tasri' dan criteria utama ijtihad.

Sementara maqasid syari'ah sebagai manhaj agama dapat digunakan sebagai tawaran alternatif pengilmuan Islam dalam wilayah sosial budaya. Alasan yang dibangun adalah mempertimbangkan kenyataan bahwa persoalan hukum hanya menempati sebagian dari ruang yang tersedia dalam Islam. AlQur'an sendiri lebih banyak bicara di luar hukum, ayat-ayat hukum itu sendiri sementara kalangan menyebutnya tidak lebih dari $10 \%$. Artinya demikian luasnya area bahasan di luar hukum, dan ini perlu mendapat perhatian. Selama ini pendekatan maqasid Syari'ah didedikasikan lebih banyak digunakan dalam hukum, padahal potensinya, ia dapat juga digunakan sebagai manhaj dalam konstruk keilmuan budaya misalnya. Dalam hal ini, makna syari'ah bisa diambil dari makna lainnya, yaitu "tempat mengalirnya air" seperti dalam QS. AlMaidah/5: 48, "Untuk tiap-tiap umat di antara kamu, kami berikan aturan (syir'ah) dan jalan (minhaj)." Menurut Muhammad Said al-Asymawi, ayat ini dimaksudkan bahwa "Kami menjadikan jalan dan metode bagi tiap-tiap kamu, atau Kami (buatkan) jalan masuk bagi kalian. "8 Dengan memaknai syari'ah sebagai tempat jalannya sesuatu (jalannya air), maka makna Syari'ah lebih dimaknai sebagai jalannya agama atau manhaj agama. Implikasi dari makna ini besar atau lebih besar dari sekedar tasyri'. Seperti diyakini di kalangan Muslim, Islam hadir dalam dunia ini dengan maksud agung yaitu rahmatan li al-alamin dan inilah manhaj agama Islam sebagai agama rahmat. Semua konstruksi doktrin, ajaran ataupun ilmu didasarkan pada prinsip dasar manhaj 
Islam yaitu rahmatan li al-alamin. Tafsir sosial Kuntowijoyo mengambil makna maqasidi sebagai manhaj din, karena tafsir sosialnya tidak didasarkan pada usul al-fiqh, tapi pada prinsip ilmu sosial. Sebelum mendiskusikan corak pemikirannya, terlebih dahulu hubungan tafsir maqasid dan Islamimisasi ilmu pengetahuan didiskusikan.

\section{Tafsir Maqasidi dan Islamisasi Ilmu Pengetahuan}

Islamisasi ilmu pengetahuan adalah sebuah gerakan intelektual internasional yang muncul tahun 1980an untuk merespon dampak negatif perkembangan sains modern. Di antara figur sentral yang menyerukan gerakan ini adalah $\mathrm{S}$ Naquib Alatas dan Ismail Raji-al-Faruqi. ${ }^{9}$ Asumsi dasar diperlukannya gerakan Islamisasi ilmu pengetahuan adalah adanya anggapan bahwa perkembangan ilmu pengetahuan modern yang dimotori oleh sains berkembang menjauhi agama dan membawa dampak negatif yang destruktif. Islamisasi diperlukan untuk memberikan alternatif epistemologis untuk mendekatkan kembali ilmu pengetahuan pada agama dan mengurangi dampak destruktif aplikasi ilmu dan teknologi yang diciptakan manusia. Di antara tawarannya adalah adanya tauhid atau kesatuan pengetahuan (menuju kebenaran yang satu), kesatuan kehidupan (hapusnya ilmu yang sarat nilai dan ilmu yang bebas nilai) dan kesatuan sejarah (pengetahuan harus mengabdi pada umat dan manusia). Dengan kata lain, Islamisasi ilmu pengetahuan adalah gerakan yang mengembalikan ilmu pengetahuan pada tauhid dengan arah gerak dari konteks menuju teks, agar supaya ilmu tidak lepas dari keimanan. ${ }^{10}$

Kemungkinan Islamisasi ilmu pengetahuan dilakukan dapat dilacak dari sisi perbedaan teori ilmunya (epistemploginya). Perbedaan tersebut bagi pengusung Islamisasi terletak pada kenyataan ilmu pengetahuan tidak bisa sama sekali bebas dari subyektivitas ilmuan. Karena itu, ilmu pengetahuan menjadi plural dan tidak bisa diklaim hanya milik salah satu bangsa, misalnya Barat. Dengan demikian, Islamisasi ilmu pengetahuan menjadi mungkin. Mulyadhi Kartanegara menganggap perlu adanya Islamisasi Ilmu pengetahuan karena ilmu pengetahuan modern telah menimbulkan persoalan serius baik secara teologis maupun keilmuan. Secara teologis ilmu pengetahuan telah menjauhkan manusia dari Tuhannya. Sementara secara praktis, pembatasan sains modern atas obyek ilmunya hanya pada obyek-obyek yang dapat diindra saja bermasalah, karena membatasi obyek ilmu lainnya yang dapat ditangkap dengan akal dan intuisi. ${ }^{11}$ Walaupun akal dalam tradisi keilmuan Barat dihargai, dalam perkembangan tradisi sains, produksi ilmu melalui akal dikritik karena 
unsur spekulasinya dan produksi ilmu melalui intuisi dikritik, karena bersifat halusinasi belaka. ${ }^{12}$

Dalam pandangan Kartanegara Islamisasi ilmu pengetahuan yang dikembangkan dalam rangka merespon dikhotomi ilmu pengetahuan yang ada mesti diarahkan pada gerakan integrasi ilmu pengetahuan holistik yang didasarkan pada tauhid. Mengambil konsepsi wahdat al-wujud Mulla Sadra, Kartanegara mendasarkan basis otologi integrasi keilmuannya. Mulla Sadra menjelaskan bahwa

"segala wujud yang ada -dengan segala bentuk dan karakternya- pada hakikatnya adalah satu dan sama. Yang membedakan satu dari lainnya hanyalah gradasinya (taskik al-wujud) yang disebabkan oleh perbedaan dalam esensinya. Oleh karena mereka pada dasarnya satu dan sama, maka wujud apapun yang kita ketahui -yang bersifat spiritualkah atau yang material- tentunya mempunyai status ontologis yang sama-sama kuatnya dan sama-sama realnya. Dan karena itu segala tingkat wujud boleh menjadi obyek yang valid bagi ilmu karena realitas ontologis mereka telah ditetapkan (fixed)."13

Kartanegara menjadikan konsepsi tauhid Mulla Sadra sebagai basis integrasi ilmu pengetahuan dari sisi obyek, sumber, klasifikasi dan metode ilmu pengetahuan. ${ }^{14}$ Dengan perspektif tauhid ilmu ini, penelitian ilmiah dapat dilakukan tidak terbatas pada obyek penelitian tajribi (experimental), tapi juga burhani (demonstratif atau aqli), dan irfani (intuitif/gnostik). ${ }^{15}$ Keragaman obyek ilmu baik fisik, matematik maupun metafisik perlu jenis ilmu tertentu walau pada hakikatnya semua wujud ilmu sama. Untuk obyek-obyek fisik memerlukan jenis ilmu yang cocok dengannya, contohnya minerologi untuk benda-benda mineral. ${ }^{16}$

Islamisasi ilmu pengetahuan diterjemahkan Kartanegara sebagai integrasi ilmu. Integrasi ilmu dikonstruksi dengan meletakkan basis ilmu pengetahuan pada realitas mutlak atau Tuhan sehingga semua ilmu yang ada berasal dariNya. Perbedaan satu ilmu dengan lainnya bukanlah pemisahan atau dikhotomi, tapi hanya merupakan penjenisan atau pemilahan saja. Dalam pertimbangannya integrasi dapat dilakukan pada obyek, bidang metafisik, matematika dan fisika, sumber ilmu, pengalaman manusia, metode ilmiah, penjelasan ilmiah, serta ilmu teoritis dan ilmu praktis. ${ }^{17}$ 


\section{Sainstifikasi atau Pengilmuan}

Saintifikasi atau pengilmuan adalah kebalikkan dari gerakan intelektual sebelumnya yang berangkat dari konteks ke teks, tapi merupakan gerakan intelektual yang berangkat dari teks ke konteks. Gerakan ini di Indonesia salah satunya digagas oleh Kuntowijoyo. Dia menyebut gerakan ini sebagai "demistifikasi". Tujuan dari gerakan ini adalah untuk menghadirkan Islam sebagai agama yang menjadi inspirasi pembuatan teori ilmiah, baik pada aspek fisik, sosial, simbolis, maupun sejarah. Interaksi antar agama dan ilmu pengetahun di sini dilakukan dengan cara menggali teori dari sumber Islam. ${ }^{18}$ Dia mengkonstruksi upayanya dengan menempatkan al-Qur'an sebagai paradigma atau mode of thought atau mode of inquiry, terinspirasi dari peristilahan yang dibuat oleh Thomas Khun. Produksi dari aplikasi paradigma tertentu adalah mode of knowing atau cara mengetahui tertentu. Cara tersendiri inilah yang disebut Kontowijoyo sebagai proses pengilmuan. Pengilmuan atau perumusan teori yang dideduksi dari al-Qur'an disebutnya sebagai paradigma al-Qur'an. Dia merumuskannya sebagai "suatu konstruksi pengetahuan yang memungkinkan kita memahami realitas sebagaimana al-Qur'an memahaminya." Kata-kata "sebagaimana al-Qur'an memahaminya," dapat diartikan sebagai cara menggali intensi dan maksud Allah dengan pesannya yang terkandung dalam al-Qur'an. Artinya, tawaran metodologisnya bersifat maqasidi. Dengan menempatkan al-Qur'an sebagai paradigma, Kuntowijoyo berusaha untuk memberi aksiologi dan epistemologi khas al-Qur'an. Dalam pandangannya al-Qur'an terdiri dari konsep-konsep dan kisah-kisah sejarah atau amtsal. Konsep memuat ideal-type tentang sesuatu atau nilai atau norma tertentu, sementara kisah dan amtsal memuat arche-type tentang hikmah atau kebijaksaan tertentu. Perumusan paradigm al-Qur'an dikaitkan dengan tugas utama Muslim di dunia. Dengan merujuk pada QS. Ali Imran: 110 yang menegaskan bahwa umat Islam adala umat terbaik diturunkan untuk tugas melakukan kebaikan (amar ma'ruf dan nahi mungkar). Inilah tugas propetif setiap Muslim, yaitu melakukan humanisasi, emansipasi dan transendensi. ${ }^{19}$

Kuntowijoyo menempatkan wahyu sebagai struktur transendental atau "ide murni," sehingga pokok konstruksi ilmu dalam pandangannya adalah untuk mencari pesan universal atau transendental al-Qur'an. Dengan cara seperti ini maka pesan al-Qur'an bisa diarahkan untuk "kemaslahatan umat manusia. ${ }^{20}$ Dalam kajian tafsir maqasidi konsep kemaslahatan umat manusia dimaknai sebagai pencarian makna signifikansi yang didasarkan pada 
kemanfaatan umum, masalih, atau sering disebut masalih mursalah karena bersifat independen dari sumber pokok agama (Wahyu dan Sunnah). Dalam tradisi Barat, kemaslahatan umum sering ditermakan sebagai public interest atau kepentingan umum, yaitu suatu cara berpikir yang didasarkan pada pertimbangan-pertimbangan kebaikan umum. Dalam hal ini kelihatannya Kuntowijoyo mempersamakan kesemuan istilah tersebut dengan kecenderungan seperti diakuinya sendiri, yaitu konstruksi pengilmuan al-Qur'an dengan meminjam perangkat analisis dari tradisi Barat. Peminjaman ini dianggapnya sebagai sesuatu yang biasa, karena pada dasarnya ilmu pengetahuan itu bersifat terbuka, dan tawaran paradigma al-Qur'annya juga bersifat terbuka. ${ }^{21}$ Dia menyebut pendekatannya ini dengan strukturalisme transendental, dengan tujuan bukan untuk memahami Islam tapi untuk suatu upaya "bagaimana menerapkan ajaran-ajaran sosial yang terkandung dalam teks lama pada konteks sosial masa kini tanpa mengubah strukturnya."22 Identifikasi analisis strukturalisme transendental pada dua level: struktur permukaan dan struktur dalam dengan tujuan menyingkap makna terdalamnya atau struktur dalam. Dia ilustrasikan dalam sebuah bagan yang menempatkan tauhid sebagai kekuatan pembentuk struktur:

Table $1^{23}$

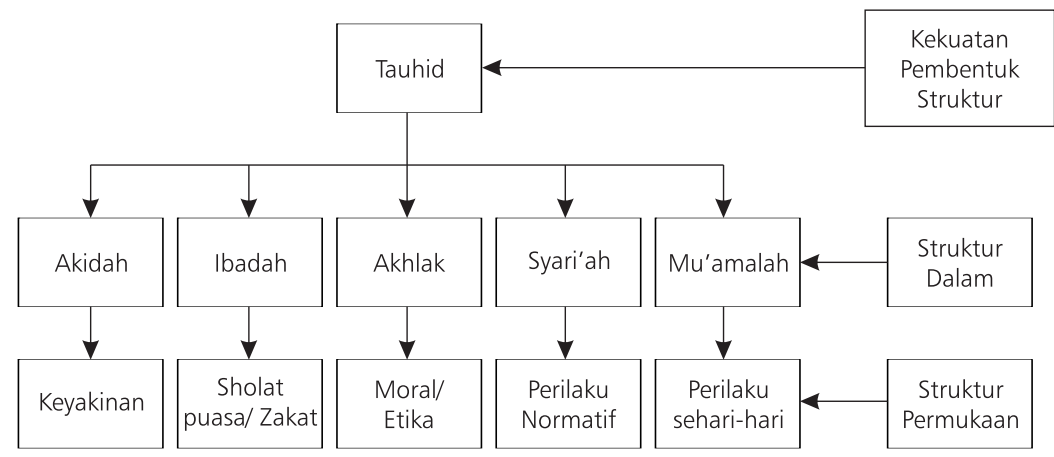

Tauhid adalah kekuatan pembentuk struktur, yaitu Tuhan Esa itu sendiri yang merupakan realitas mutlak, hakikat atau kebenaran itu sendiri. Tauhid kemudian membentuk struktur dalam yang bersifat tetap seperti akidah, ibadah, akhlak,syari'ah dan yang bersifat dapat berubah, yaitu muamalah. Aspek muamalah inilah yang menjadi medan ijtihad untuk pengilmuan Islam. Sementara aspek lain dalam pandangannya dianggap transformasinya sudah selesai. Jadi esensi dari keyakinan, sholat, zakat, dll, moral/etika, dan perilaku 
normatif sudah dianggap utuh. Yang perlu mendapat perhatian untuk penggalian kosntruksi baru adalah mua'malah. Untuk melakukannya dalam pandangan Kuntowijoyo, umat Islam perlu memperluas kesadarannya. Setidaknya dia mengusulkan enam kesadaran yang perlu dimiliki umat Islam: 1. kesadaran tentang perubahan, 2. kesadaran kolektif, 3. kesadaran sejarah, 4. kesadaran tentang fakta sosial, 5. Kesadaran tentang masyarakat abstrak, dan 6. Kesadaran tentang perlunya obyektifikasi. ${ }^{24}$

Dengan pemenuhan enam kesadaran di bangun di atasnya proses obyektifikasi yang Kuntowijoyo namakan integralisasi ilmu dan atau transformasi ilmu sosial profetik. Ilmu-ilmu integralistik adalah proses obyektifikasi konstruksi ilmu pengetahuan untuk memelihara keberlangsungan ilmu itu sendiri dengan memasukkan kembali pentingnya peran agama. IImu-ilmu integralistik tidak bersikap berlawanan terhadap atau mengganti ilmu-imu sekuler, tapi sebaliknya bersikap positif secara proporsional untuk "berada bersama ilmu-ilmu sekuler (Barat dan Marxist)."25 Dia menggambarkan hubungan ilmu-ilmu sekuler dan paradigm Islam seperti table di bawah ini:

\begin{tabular}{|c|c|c|c|c|c|}
\hline & PERIODE & SUMBER & ETIKA & PROSES SEJARAH & ILMU \\
\hline $\begin{array}{l}\text { Barat } \\
\text { Islam }\end{array}$ & $\begin{array}{l}\text { Modern } \\
\text { Pasca modern }\end{array}$ & $\begin{array}{l}\text { Akal } \\
\text { Wahyu, akal }\end{array}$ & $\begin{array}{l}\text { Humanisme } \\
\text { Humanisme } \\
\text { Teosentrisme }\end{array}$ & $\begin{array}{l}\text { Diferensiasi } \\
\text { Dediferensiasi }\end{array}$ & $\begin{array}{l}\text { Sekuler, otonom } \\
\text { Integralistik }\end{array}$ \\
\hline
\end{tabular}

Sebagaimana dipetakan dalam table di atas, karakteristik ilmu-ilmu sekuler (Barat) pada periode modern adalah sumbernya akal, etikanya humanis, proses sejarahnya dimulai dari pemusatan manusia sebagai pusat dan kemudian memisahkan ilmu dari agama, dan sifat ilmunya sekuler dan otonom. Sementara, paradigm Islam ditempatkan di periode pasca modern, dengan menempatkan wahyu dan akal sebagai sumber karena sikap teosentrismenya, dengan etika humanis dan teosentris, kemudian melakukan upaya dediferensiasi atau menggabungkan kembali ilmu-ilmu agama dan umum dengan semangat integralistiknya.

Di lain pihak, Kuntowijoyo juga mengusulkan gerakan obyektifikasi ke dua dimana dia mengusulkan Ilmu sosial profetik. Obyektitifikasi dimulai dari proses internalisasi nilai-nilai, seperti meyakini baiknya perbuatan zakat. Langkah selajutnya dari obyektivikasi adalah ekternalisasi, yaitu mengonkritkan apa yang diyakini, seperti ketika seorang Muslim membayar zakat. Membayar 
zakat merupakan obyektivikasi pada tingkat ekternalisasi dengan keyakinan bahwa hal tersebut dilakukan untuk membersihkan harta, dan sebagian dari yang kita peroleh ada hak orang lain, dan keyakinan bahwa rezeki itu mesti dinafkahkan. Hal lain yang perlu diperhatikan dari obyektifikasi adalah tindakan obyektif dan dampak tindakan obyektif. Tindakaan obyektif adalah adalah tindakan yang sesuai dengan prinsip-prinsip universal atau umum sementara dampak dari tindakan obyektif adalah apabila dirasakan oleh orang lain termasuk bagi non Muslim sebagai tindakan yang alamiah/natural atau sewajarnya. Dengan cara demikian, obyektifikasi itu akan menghindarkan dari tindakan dominasi, sekularisasi dan juga terbuka bagi siapa saja ${ }^{27}$ atau Islam menjadi rahmatan lil alamin.

Dengan obyektifikasi juga Kuntowijoyo mendorong umat Islam untuk memperhatikan kesinambungan agar umat Islam tidak selalu mulai dari nol. Sebagai seorang sejarawan, Kuntowijoyo sadar betul akan pentingnya kesinambungan pemikiran Islam dalam hal ini dalam konteks Indonesia. Di sini, dengan obyektifikasi, dia menunjukkan keterkaitan antara periode ilmu dengan periode sejarah politik umat Islam. Asumsi padangan ini adalah sejarah Indonesia dianggap terdiri dari pragmen-pragmen terpisah antara satu dengan lainnya. Sebenarnya tidak demikian karena antar fragmen sejarah, terdapat benang merah yang merajut kesinambungannya. Perbedaan karakteristik yang ada dalam sejarah Islam di Indonesia misalnya dapat dikategorikan sebagai perbedaan karakterisktik dari satu unit atau periode ke unit atau periode lainnya. Mengetahui periode-periode tersebut menjadi penting karena umat menjadi tahu apa yang mesti dilakukan untuk menjawab pertanyaan What is to be done? Kuntowijoyo mengilustrasikan perkembangan periode-periode umat Islam Indonesia, seperti dalam table di bawah ini:

\begin{tabular}{llll}
\multicolumn{4}{c}{ Periodisasi Sejarah Umat ${ }^{28}$} \\
\hline DASAR: NILAI-NILAI ISLAM & MITOS & IDEOLOGI & ILMU \\
\hline Cara Berpikir & Pralogis & Nonlogis & Logis \\
Bentuk & Magi & Abstrak/apriori & Konkrit/empiris \\
\hline
\end{tabular}

Dalam periode mitos, cara berpikir umat adalah pralogis atau mistis, menghargai mitos. Karakteristiknya adalah pergerakan politik banyak mengambil tempat di pedesaan, atau bersifat lokal, dengan latar belakang ekonomi agraris, masyarakat pedesaan, solidaritas mekanik, dan model kepemimpinan kharismatik, serta sasaran perjuangan adalah pemerintahan 
kolonial. Sementara dalam periode ideologi, cara berpikirnya rasional tapi non-logis, "berbentuk pengetahuan apriori tentang nilai-nilai abstrak, lokasi kota, perkumpulan yang bersifat nasional, ekonomi komersial dan industri kecil, masyarakat pedagang dan 'partikelir', solidaritas organis, dan kepemimpinan intelektual." Periode ini ditandai dengan berdirinya organisasi politik massa atau dia menyebutnya wong cilik (rakyat kecil), yaitu SI tahun 1911. Kalau di periode sebelumnya, perjuangan umat diwujudkan dalam bentuk pemberontakkan, dalam periode ini diwujudkan dalam bentuk "pengerahan massa untuk tujuan-tujuan damai." Terakhir periode ilmu, terjadi sejak tahun 1985 ketika ideolgi harus berganti dengan Pancasila. Bagi sebagian ini kerugian yang sangat besar dan bahkan Islam dianggap kehilangan segalanya. Kuntowijoyo melihat bahwa mereka yang menganggap demikian menujukkan kualitas berpikir pendek. Apa yang sebenarnya terjadi adalah bahwa sejarah sedang berkembang menuju periode ilmu dimana salah paham dalam berbagai hal dapat diurai. Para pemikir ketika itu sudah mulai mencoba menjelaskan keadaan sebenarnya dan merumuskan apa yang mesti dikerjakan. Misalnya, Nurcholish Madjid dengan gerakan budayanya seperti semboyan 'Islam Yes dan Partai Islam No,' atau Quraish Shihab dengan istilah Membumikan al-Qur'an. Sementara kontowijoyo sendiri menawarkan Paradigma Islam dengan obyektifikasinya. Periode ilmu ini ditandai dengan cara berpikir umat mulai logis dengan memperhatikan kekongkritan sesuatu dan hal-hal empiris. ${ }^{29}$

Selain yang ditawarkan oleh Kuntowijoyo, sebenarnya banyak sarjana lain yang juga menawarkan alternatif paradigma, pendekatan dan metodologi keilmuan dengan semangat pengilmuan Islam. Dalam tradisi tafsir, perkembangan penggunaan metode tafsir tematik misalnya mempunyai semangat pengilmuan Islam dimana relasi teks dan konteks dianalis untuk menghadirkan perspektif al-Qur'an tentang sesuatu konsep. Misalnya, karya 'Aishah 'Abd al-Rahman bintu Shati al-Qur'an wa Qadaya al-Insan (1982), atau Fazlur Rahman dengan Tema Pokok al-Qurannya (1983) dapat juga dimasukkan dalam kategori ini karena dalam karyanya dia berusaha menghadirkan perspektif al-Qur'an tentang sejumal tema bahasan. Di bidang lain, misalnya karya Ilyas ba-Yunus dan Farid Ahmad Sosiologi Islam dan Masyarakat Islam Kontemporer (1991, cte. 1, 1988), atau Hasan Hanafi dengan kajian Oksidentalisme, dan Thahir Ibn Atsur dan Jase Audah dengan maqasidnya, dkk. 


\section{Signifikansi Pemikiran Kuntowijoyo}

Islamisasi ilmu pengetahuan adalah salah satu gerakan pemikiran sarajana Muslim dalam merespon perjumpaan antara modernitas dengan Islam. ${ }^{30}$ Istilah Islamisasi ilmu pengetahuan itu sendiri merupakan wacana yang lebih banyak didukung oleh praktik yang bersifat politis dari upaya koreksian atau "tawaran Islami" intelektual Muslim atas perkembangan keilmuan yang ada daripada upaya akademik yang serius dalam menghadirkan filsafat keilmuan alternatif. ${ }^{31}$ Namun demikian gerakan Islamisasi ilmu pengetahuan terus bergulir, dan salah satunya melalui gerakan maqasid syari' ah, termasuk di dalamnya tafsir maqasidi. Walaupun tafsir maqasidi merupakan wilayah hermeneutika fikih dalam memahami pesan Allah, cakupan isi al-Qur'an lebih luas dari hanya wilayah hukum. Oleh karena itu, tafsir maqasidi berpotensi menggali pesan, norma, sistem, praktik sosial, pengetahuan, bahkan konstruksi ilmu pengetahuan.

Secara umum gerakan Islamisasi Ilmu pengetahuan pertama kali muncul dalam sebuah konferensi di Mekkah pada tahun 1977, dimana Naquib AlAttas mengungkapkan pentingnya gerakan Islamisasi ilmu pengetahuan dalam konteks pendidikan, sementara Ismail R. al-Faruqi dalam konteks Islamisasi ilmu-ilmu sosial. ${ }^{32}$ Sebenarnya kesadaran akan pentingnya Islamisasi ilmu pengetahuan dapat dirunut telah lebih awal lagi, seperti kesadaran akan penting ekonomi Islam telah muncul sejak tahun 1930an, ${ }^{33}$ sementara akan pentingnya pandangan dunia Islam dan menglslamkan ilmu sudah muncul sejak tahun 1950s dalam karya Sayyid Hussein Nars misalnya. ${ }^{34} \mathrm{Al}$-Faruqi sendiri meneruskan gagasan tersebut dan mendirikan lembaga kajian di Ameri Serikat, yaitu The International Institute of Islamic Thought and Civilization, dikenal sebagai IIIT.35

Salah satu gerakan Islamisasi ilmu pengetahuan yang menjadi fokus IIIT saat ini adalah pengembangan wacana maqasid syari'ah. Maqasid syari'ah pada awalnya digali berdasar pada tiga pertimbangan dasar, yaitu darurat (keniscayaan), hajiyyat (kebutuhan), dan tahsiniyyat (kelengkapan hidup), dimana pertimbangan dasar pertama menjadi pokok ukuran yang secara tradisional didasarkan pada pemeliharaan lima hal: keimanan (faith), jiwa (soul), kekayaan (wealth), akal (mind), dan keturunan (offspring), dan sebagian menambahkan kehormatan (honor). ${ }^{36}$ Namun dalam perkembangannya pennggunaan konsep maqasidi tidak hanya didasarkan pada pertimbangan individual seperti tercermin dalam pengertiannya yang tradisional, tapi juga dimensi prinsip dasarnya diperluas pada kepertimbangan nilai-nilai universal, 
yaitu maqasid universal, dimana proses tafsir atau ijtihad didasarkan pada dasar-dasar universal yang terdapat dalam Islam khususnya dalam al-Qur'an. Jasser Auda memformulasikannya sebagai struktur multidimensi yang mempertimbangkan area makna dan target, tingkatan nilai yang dijadikan dasar, dan keumuman makna yang dikandung. ${ }^{37}$ Dengan pengertian tersebut, pengertian maqasid mengalami transformasi ke arah lebih luas, umum dan universal. Misalnya, Al-Tahir ibn Ashur mengusulkan perluasan dasar pertimbangan maqasid pada menjaga dan memelihara ketertiban (orderliness), kesejajaran (equality), kebebasan (freedom), facilitation (pendasaran untuk menciptakan keadaan yang membantu), dan pemeliharaan fitrah (kualitas alamiah akal dan sifat-sifat manusia), ${ }^{38}$ dan Jasser Audah yang menawarkan pendekatan sistem untuk merekonstruksi pemikran hukum, hak asasi manusia, keadaban, dan tatakelola berdasarkan pemikiran prinsip nilai dan hukum Islam. Menurut Anas al-Shaikh-Ali, Direktur Akademik, IIT Kantor London, karya Audah ini menyajikan:

A systems approach to the philosophy and juridical theory (usul) of Islamic law based on its purposes, principles, higher objectives, and ends (maqasid al-shari»ah). For Islamic rulings to fulfil their purposes of justice, equality, human rights, development, and civility in today's context, the author places maqasid, as the group of divine intents and moral concepts, at the heart and basis of Islamic law. He introduces a novel method of analysis, classification, and critique that utilizes relevant features from systems theory such as wholeness, multidimensionality, openness, cognitive nature and especially purposefulness of systems. More broadly, this systematical methodological approach has implications for the reconstruction of the law, human rights, civil society, and governance anchored in Islamic principles and juridical thought. ${ }^{39}$

(Suatu pendekatan system terhadap teori filsfat dan pokok-pokok hukum (usul) dari hukum Islam berdasarkan maksud-maksud, prinsi-prinsip, tujuantujuan mulia, dan goal-goalnya (maqasid al-shari»ah). Untuk aturan-aturan Islam memenuhi tujuan keadilan, kesetaraan, hak asasi manusia, pengembangan, dan keadabannya dalam konteks sekarang, pengarang menempatkan maqasid sebagai kelompok tujuan-tujuan ilahi, konsepkonsep moral, pada inti dan dasar dari hukum Islam. Dia mengenalkan suatu metode analisis, kalsifikasi dan kritik baru yang menggunakan karakteristik-karakterisk relevant dari teori system seperti prinsip keseluruhan, multidimensionalitas, keterbukaan, fitrah akal, dan khususnya kebermak- 
sudan sistem. Lebih luas lagi, pendekatan metodologis sistematis ini mempunyai implikasi untuk upaya rekonstruksi hukum, hak asasi manusia, civil society, dan tatakelola yang dijangkarkan pada prinsip-prinsip dan pemikiran hukum Islami.)

IIIT memfasilitasi penyebaran gagasan maqasidi salah satunya dengan cara menerjemahkan karya-karya pemikir Islam seputar maqasid al-shari»ah, seperti karya Jasser Auda, Maqasid Syari'ah as Philosophy of Islamic Law: A System Approach, (2007), Thahir Ibn Ashur, Maqasid al-Shari»ah, Ahmad Raysani, Imam al-Shamibi's Theory of the Higher Objectives and Intents of Islamic Law, and Gamal Eldine Attia Towards Realization of Higher Intents of Islamic Law: Maqasid al-Shari»ah as Functional Approach. ${ }^{40}$

Jasser Auda mengajukan pendekatan sistem untuk membangun kerangka pikir baru dalam pengembangan hukum Islam. Alasannya, penerapan atau aplikasi hukum Islam sekarang lebih bersifat reduktif (kurang utuh) dari pada utuh, lebih menekankan makna literal dari pada moral, lebih terfokus pada satu dimensi saja dari pada multidimensi, nilai-nilai yang dijunjung tinggi lebih bercorak hitam-putih dari pada warna-warni pelangi, bercorak dekonstruktif dari pada rekonstruktif, kausalitas dari pada berorientasi pada tujuan teleologis. ${ }^{41}$

Ada enam fitur sistem yang dioptimalkan Auda sebagai pendekatan atau pisau analisisnya, yaitu kognisi (cognition), kemenyeluruhan (wholeness), keterbukaan (openness), interkonektifitas (interconnectedness), multidimensi (multidimensionality) dan selalu mengacu kepada tujuan utama atau kebermaksudan (purposefulness). ${ }^{42}$ Hasil teoritis dari enam fitur tersebut ingin menegaskan, bahwa metode validitas apapun dari ijtihad ditentukan berdasarkan derajat realisasi maqasid Syariah. Hasil praktisnya ialah hukum Islam yang sesuai untuk nilai-nilai keadilan, perilaku moral, kemurahan hati, ko-eksistensi (hidup berdampingan), dan pembangunan manusia. Dasar penting Auda menulis maqashid syari'ah sebagai sebuah sistem adalah keadilan, kasih-sayang, kebijaksanaan dan kebaikan yang menghendaki kesejahteraan manusia di dunia dan akhirat. ${ }^{43}$ Esensi dari hukum Islam adalah, merupakan motor penggerak untuk keadilan, produktivitas, pembangunan, perikemanusiaan, spiritual, kebersihan, persatuan, keramahan, dan masyarakat demokratis. Persoalannya adalah bahwa realitas Muslim saat ini dalam pengamatan Audah belum mampu secara kuat mewujudkan nilai-nilai tersebut dalam kehidupan sehari-hari. Tantangannya adalah bagaimanakah hukum Is- 
lam berperan dalam memecahkan persoalan ini? ${ }^{44}$

Meskipun tidak didasarkan pada ushul al-fiqh, tawaran metodologis Kuntowijoyo dalam konteks wacana tafsir maqasid adalah relevan dan signifikan. Tawaran Kuntowijoyo dianggap relevan karena adanya kesamaan semangat mendasarkan pada nilai dan prinsip dasar Islam, khususnya al-Qur'an dalam upaya rekonstruksi pemikiran keislaman. Tawaran tersebut dapat aplikasikan untuk menjawab masalah-masalah kontemporer seperti yang digagas Kuntowijoyo sendiri atau dimanfaatkan sebagai frame pendekatan maqasid lainnya. Pendekatan Kuntowijoyo tentang strukturalisme transendental dapat diaplikasikan untuk mendiskusikan lebih lanjut wacana tafsir maqasidi. Dalam hal ini prinsip dasarnya, yaitu tauhid dapat didudukan sebagai kekuatan pembentuk struktur dan dia merupakan realitas mutlak atau kebenaran itu sendiri dan menjadi sumber, dan tujuan penelitian. Kemudian, dalam struktur dalam, dapat kita masukkan prinsip-prinsip maqasid Syari'ah. Karena penentuan karakteristik-karakteristik maqasid syari'ah bersifat ijtihadi, maka setiap pemikir terbuka kesempatan untuk merumuskan sendiri atau bersepapakat dengan pemikir lainnya. Misalnya, apa yang telah dirumuskan Tahir ibn Atsur sebagai bahan diskusi, yaitu: 'orderliness (ketertiban), equality (kesetaraan), freedom (kebebasan), facilitation (bersifat menyediakan), dan the preservation of pure natural disposition (fitrah),'45 atau yang ditawarkan Audah: sistem keadilan, kesetaraan, hak asasi manusia, keadabannya seperti kasih-sayang, kebijaksanaan dan kebaikan yang menghendaki kesejahteraan manusia di dunia dan akhirat. ${ }^{46}$

Selanjutnya, struktur permukaan, yaitu konsep, nilai, norma dan realitas dan berbagai persoalan yang terdapat dalam kehidupan, serta hubungan keduanya, yang didudukan sebagai obyek atau input dimana ijtihad atau reinterpretasi dengan pendekatan maqasisi syari'ah dapat dilakukan. Secara ringkas dapat diilustrasikan seperti ini: 
Maqasid Syari'ah: 'orderliness (ketertiban), equality (kesetaraan), freedom (kebebasan), facilitation (bersifat menyediakan), dan the preservation of pure natural disposition (fitrah)

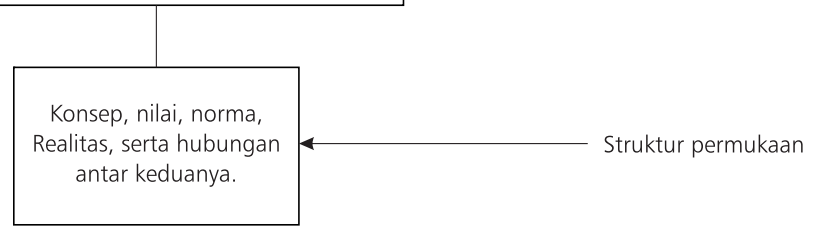

Atau Model Jasser Audah seperti berikut:

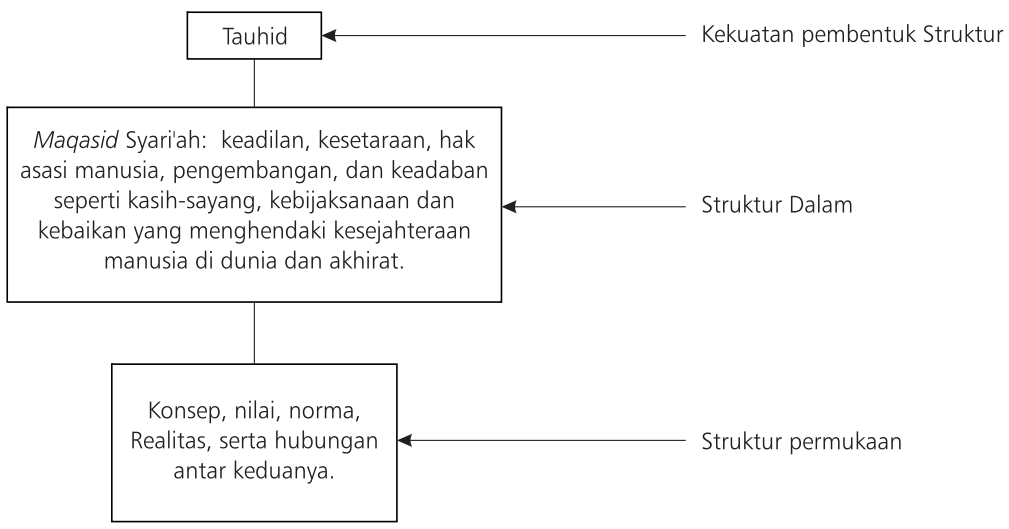

Walaupun tawaran pendekatan Kuntowijoyo tidak lekang dari kritikan para sarjana akan proyek Islamisasi ilmu pengetahuan secara umum seperti disinggung di atas, dan dalam hal ini pemikirannya terkesan esensialis dan tertumpu pada pendekatan normatif atas persoalan-persoalan empiris, tidak dapat dipungkiri gagasan pengilmuan Islam melalui pendekatan paradigma Islam merupakan kontribusi penting dalam wacana rekontsruksi pemikiran keislaman dalam ranah yang lebih luas dari hanya seputar ranah hukum dimana wacara tafsir maqasidi selama ini dikonstruksi, yaitu sosial budaya. Ranah ini merupakan ranah yang sangat luas dan penting, karena bersentuhan langsung dengan banyak aspek kehidupan manusia. Tarawannya berpotensi dapat diaplikasikan secara luas dan mengangkat pendekatan tafsir maqasidi ke level lainnya, yaitu kajian sosial budaya. 


\section{SIMPULAN}

Paradigma al-Qur'an Kuntowijoyo merupakan upaya ijtihad individual untuk merekonstruksi pemahaman keagamaan agar dapat digunakan pada konteks kekinian di Indonesia. Pendekatan strukturalisme transendental yang digagasnya sebenarnya bertumpu pada pentingnya tauhid sebagai landasan epistemologis konstruksi ilmu pengetahuan. Penggunaan tauhid sebagai landasan tidak hanya keimanan tapi juga keilmuan merupakan common flatform semua penggagas Islamisasi ilmu pengetahuan, meskipun Kuntowijoyo sendiri tidak menamakan tawarannya sebagai proyek Islamisasi, tapi obyektifikasi keilmuan. Meski demikian, saja paradigm al-Qur'an tetap tidak lepas dari semangat proyek Islamisasi ilmu pengetahuan. Yang menarik dari paradigm al-Qur'an Kuntowijoyo sebenarnya terletak pada potensi gagasan didudukkan sebagai proyek gerakan tafsir maqasidi tapi dalam konteks yang lebih luas yaitu manhaj aldin atau metodologi kajian agama (Islam). Dalam titik ini, gagasan Kuntowijoyo dapat dikategorikan sebagai avant garde tafsir maqasidi yang mencoba menurunkan nilai dan norma keislaman dalam konteks kontemporer dunia Islam umumnya, dan khususnya kontemporer Indonesia.

\section{Catatan Akhir}

*) Makalah ini adalah bagian dari penulisan makalah tentang integrasi keilmuan yang dipresentasikan di Fakultas Syari'ah dan Hukum UIN Syarif Hidayatullah Jakarta tahun 2014, dan hasil penelitian individual untuk publikasi di jurnal nasional terakreditasi dengan dana bantuan dari UIN Syarif Hidayatullah anggaran tahun 2015. Sebagian materi dari makalah ini telah diterbitkan dalam bahasa Inggris di Jurnal Islamika Indonesiana Volume 1 No 2 tahun 2014.

1 Jasser Auda. 2007. Maqasidi al-Syari'ah as Philosophy of Islamic Law. London dan Washington: The International Institute of Islamic Thought, p. 2-8.

2 Auda. 2007. Maqasidi al-Syari'ah, h. 8.

3 Auda. 2007. Maqasidi al-Syari'ah, h. 6.

4 Yusuf al-Qardhawi. 2006. Fiqh maqashid Syari'ah: Moderasi Islam antara Aliran Tekstualis dan Aliran Liberal. Jakarta: Pustaka al-Kautsar, h. 37-40.

5 Husein Muhammad. 2007 (Cet. Ke 4). Fikih Perempuan: Refleksi Kiai atas Wacana Agama dan Gender. Yogyakarta: LKiS, 186-7.

6 M. Quraish Shihab. 1993. "Konsep Wanita Menurut Qur'an, Hadis, dan Sumber-sumber Ajaran Islam," dalam Wanita Islam Indonesia dalam Kajian tekstual dan Kontekstual di edit oleh Lies M. Marcoes-Natsir dan Johan Hendrik Meuleman. Jakarta: INIS, h. 4.

7 Muhammad Yusuf. 2013. "Pendekatan al-Maslahah al-Mursalah dalam Fatwa MUI tentang Pernikahan Beda Agama,” dalam Ahkam Jurnal Ilmu Syari'ah. Vol. 
XIII, No. 1 (Januari 2013), h. 101-2.

8 Muhammad Said al-Asymawi. (1983 dalam edisi aslinya, 2004 edisi terjemahnya). Nalar Kritis Syari'ah. Yogyakarta: LKiS, h. 20-21.

9 Kuntowijoyo. 2004. Islam sebagai Ilmu: Epistemologi, Metodologi dan Etika. Jakarta: Teraju, h. 7-8.

10 Kuntowijoyo. 2004. Islam sebagai Ilmu, h. 8.

11 Mulyadhi Kartanegara. 2007. MengIslamkan Nalar: Sebuah Respon terhadap Modernitas. Jakarta: Penerbit Erlangga, h. 1-13.

12 Mulyadhi Kartanegara. 2003. Integrasi Ilmu dalam Perspektif Filsafat Islam. Jakarta: UIN Jakarta Press, h. 5.

13 Kartanegara. 2003. Integrasi Ilmu, h. 16.

14 Kartanegara. 2003. Integrasi Ilmu, h. 17.

15 Kartanegara. 2003. Integrasi Ilmu, h. 18.

16 Kartanegara. 2003. Integrasi Ilmu, h. 20-21.

17 Kartanegara. 2003. Integrasi Ilmu.

18 Kuntowijoyo. 2004. Islam sebagai Ilmu, h. 10-11.

19 Kuntowijoyo. 2004. Islam sebagai Ilmu, h. 11-16; Kuntowijoyo. 2008. "Paradigmaa al-Qur'an untuk Perumusan Teori," dalam Paradigma Islam Interpretasi untuk Aksi, Bandung: Mizan, h. 548-63.

20 Kuntowijoyo. 2004. Islam sebagai Ilmu, h. 18-26.

21 Kuntowijoyo. 2004. Islam sebagai Ilmu, h. 25.

22 Kuntowijoyo. 2001. Muslim Tanpa Masjid: Esai-esai Agama, Budaya, dan Politik dalam Bingkai Strukturalisme Transendental. Bandung: Mizan, h. 10.

23 Kuntowijoyo. 2001. Muslim Tanpa Masjid, h. 15.

24 Kuntowijoyo. 2001. Muslim Tanpa Masjid, h. 21.

25 Kuntowijoyo. 2004. Islam sebagai Ilmu, h.251-62.

26 Kuntowijoyo. 2004. Islam sebagai Ilmu, h. 61.

27 Kuntowijoyo. 2004. Islam sebagai Ilmu, h. 64-5.

28 Kuntowijoyo. 2004. Islam sebagai Ilmu, h. 81.

29 Kuntowijoyo. 2004. Islam sebagai Ilmu, h. 80-83.

30 John Cooper, "Batas-batas Yang Sakral: Epistemologi Abdul Karim Soroush," dalam Pemikiran Islam dari Sayyid Ahmad Khan hingga Nasr Hamid Abu Zayd, diedit oleh John Cooper, Ronald L. Nettler dan Mohamed Mahmoud, Jakarta: Penerbit Erlangga, 2000, h. 31.

31 Seyyed Vali Reza. 1991. "Islamization of Knowledge: A Critical Review," in Islamic Studies, vol. 30, No. 30 p. 387. pp. 387-400

32 Syed Farid al-Attas, "The Sacralization of the Social Sciences: A Critique of an Emerging Theme in Academic Discourse," dalam Archives de sciences sociales des religions, 40e Année, No. 91 (Jul.-Sep., 1995), p. 95.

33 al-Attas, "The Sacralization of the Social Sciences...," p. 89.

34 al-Attas, "The Sacralization of the Social Sciences...," p. 95.

35 al-Attas, "The Sacralization of the Social Sciences...," p. 95.

36 Jasser Auda. 2007. Maqasidi al-Syari'ah as Philosophy of Islamic Law. London dan Washington: The International Institute of Islamic Thought, p. 2-8. 
37 Auda. 2007. Maqasidi al-Syari'ah, h. 8.

38 Auda. 2007. Maqasidi al-Syari'ah, h. 6.

39 Anas S al-Shaikh-Ali. 2007. "Foreword," dalam Jasser Audah Maqasid al-Shari»ah as Philosophy of Islamic Law: A Systems Approach, London and Washington: The IIIT, p. xx.

40 al-Shaikh-Ali. 2007. "Foreword," p. ixx.

41 Auda. 2007. Maqasid al-Syari'ah as Philosophy of Islamic Law: A System Approach, London: The International Institute of Islamic Thought, p. xxvii.

42 Auda. 2015, Membumikan Hukum Islam...," h. 11. Lihat juga, M. Amin Abdullah, "Epistemologi Keilmuan Kalam dan Fikih dalam Merespon Perubahan di Era NegaraBangsa dan Globalisasi (Pemikiran Filsafat Keilmuan Agama Islam Jasser Auda)", Media Syari'ah, Vol. XIV No. 2 Juli - Desember 2012.

43 Jasser Auda, Penj. Rosidin dan 'Ali 'Abd el-Mun'im, 2015, Membumikan Hukum Islam Melalui Maqasid Syari'ah, Bandung: Mizan, h. 21-22.

44 Jasser Auda, Penj. Rosidin dan 'Ali 'Abd el-Mun'im, 2015, h. 22-23.

45 Jasser Auda. 2007. Maqasidi al-Syari'ah as Philosophy of Islamic Law. London dan Washington: The International Institute of Islamic Thought, p. 6. (Penggunaan model footnote tidak konsisten)

46 Jasser Auda, Penj. Rosidin dan 'Ali 'Abd el-Mun'im, 2015, Membumikan Hukum Islam Melalui Maqasid Syari'ah, Bandung: Mizan, h. 21-22.

\section{Daftar Pustaka}

Abdullah, M. Amin, "Epistemologi Keilmuan Kalam dan Fikih dalam Merespon Perubahan di Era Negara-Bangsa dan Globalisasi (Pemikiran Filsafat Keilmuan Agama Islam Jasser Auda)”, Media Syari'ah, Vol. XIV No. 2 Juli - Desember 2012.

al-Asymawi, Muhammad Said. (1983 dalam edisi aslinya, 2004 edisi terjemahnya). Nalar Kritis Syari'ah. Yogyakarta: LKiS.

Auda, Jasser. 2007. Maqasid al-Syari'ah as Philosophy of Islamic Law: A System Approach, London: The International Institute of Islamic Thought.

- 2015. Penj. Rosidin dan 'Ali 'Abd el-Mun'im, 2015, Membumikan Hukum Islam Melalui Maqasid Syari'ah, Bandung: Mizan. Auda, Jasser. 2007. Maqasidi al-Syari'ah as Philosophy of Islamic Law. London dan Washington: The International Institute of Islamic Thought.

Kuntowijoyo. 2004. Islam sebagai Ilmu: Epistemologi, Metodologi dan Etika. Jakarta: Teraju.

-2001. Muslim Tanpa Masjid: Esai-esai Agama, Budaya, dan Politik dalam Bingkai Strukturalisme Transendental. Bandung: Mizan.

_. 2008. "Paradigmaa al-Qur'an untuk Perumusan Teori," dalam Paradigma Islam Interpretasi untuk Aksi, Bandung: Mizan

Kartanegara, Mulyadhi. 2007. MengIslamkan Nalar: Sebuah Respon terhadap Modernitas. Jakarta: Penerbit Erlangga.

—. 2003. Integrasi Ilmu dalam Perspektif Filsafata Islam. Jakarta: UIN Jakarta Press.

al-Attas, Syed Farid, "The Sacralization of the Social Sciences: A Critique of an 
Emerging Theme in Academic Discourse," dalam Archives de sciences sociales des religions, 40e Année, No. 91 (Jul.-Sep., 1995).

Cooper, John, 2000. "Batas-batas Yang Sakral: Epistemologi Abdul Karim Soroush," dalam Pemikiran Islam dari Sayyid Ahmad Khan hingga Nasr Hamid Abu Zayd, diedit oleh John Cooper, Ronald L. Nettler dan Mohamed Mahmoud, Jakarta: Penerbit Erlangga.

Muhammad, Husein. 2007. (Cet. Ke 4). Fikih Perempuan: Refleksi Kiai atas Wacana Agama dan Gender. Yogyakarta: LKiS.

al-Qardhawi, Yusuf. 2006. Fiqh maqashid Syari'ah: Moderasi Islam antara Aliran Tekstualis dan Aliran Liberal. Jakarta: Pustaka al-Kautsar.

Reza, Seyyed Vali. 1991. "Islamization of Knowledge: A Critical Review," in Islamic Studies, vol. 30, No. 30.

al-Shaikh-Ali, Anas S. 2007. "Foreword," dalam Jasser Audah Maqasid al-Shari»ah as Philosophy of Islamic Law: A Systems Approach, London and Washington: The IIIT.

Shihab, M. Quraish. 1993. "Konsep Wanita Menurut Qur'an, Hadis, dan Sumbersumber Ajaran Islam,” dalam Wanita Islam Indonesia dalam Kajian tekstual dan Kontekstual di edit oleh Lies M. Marcoes-Natsir dan Johan Hendrik Meuleman. Jakarta: INIS, h. 4.

Yusuf, Muhammad. 2013. "Pendekatan al-Mas lah ah al-Mursalah dalam Fatwa MUI tentang Pernikahan Beda Agama,” dalam Ahkam Jurnal Ilmu Syari'ah. Vol. XIII, No. 1 (Januari 2013). 